\title{
DO PAYROLL TAX REDUCTIONS ENHANCE EMPLOYMENT? POLICY LESSONS FROM COLOMBIA ${ }^{(*)}$
}

\author{
BAIXAR AS CONTRIBUIÇÕES SOCIAIS GERA EMPREGO? \\ LIÇÕES DE POLÍTICA A PARTIR DO CASO COLOMBIANO
}

\author{
Stefano Farné $\dot{e}^{(* *)}$ \\ Universidad Externado de Colombia, Bogotá (DF), Colômbia
}

\begin{abstract}
In order to reduce the large informal sector, the Colombian government has cut payroll taxes on two occasions in two years, with the Acts of Formalization and Employment Generation, and Tax Reform. In the first case the Act was estimated to generate 500.000 new formal jobs and in the second one between 400.000 and a million. This paper contextualizes the measures implemented, evaluates their theoretical consistency and comments the first available data after enactment of the two acts. The analysis does not lead to ratify optimistic governmental forecast, in line with recent international experience. In a raw, we discuss policy implications.
\end{abstract}

Keywords: Labour demand; Non-wage labour costs; Public policy.

Resumo: Com o propósito de diminuir a elevada informalidade, o governo colombiano reduziu a carga tributária relacionada com a contratação trabalhista duas vezes em apenas dois anos, com as Leis de Formalização e Geração de Emprego e Reforma Tributária. No primeiro caso, se estima gerar 500.000 novos empregos formais e, no segundo, entre 400.000 a um milhão. Este artigo contextualiza as medidas implementadas, avalia a consistência teórica entre instrumentos empregados e resultados pretendidos e comenta os primeiros resultados ocupacionais obtidos. A análise nos leva a ratificar os otimistas prognósticos governamentais, em consonância com a recente experiência internacional. Ao final, discutem-se políticas públicas.

Palavras-chave: Demanda de trabalho; Custos não salariais e benefícios trabalhistas; Políticas públicas.

(*) This document has been possible thanks to the financial support of the International Labour Organization (ILO), Office for Argentina. The author thanks the comments of Professor José Antonio Ocampo of the University of Columbia and doctor Fabio Bertranou of the ILO Office of Buenos Aires. He also thanks the assistance of David Rodríguez, researcher at the Observatoriodel Mercado de Trabajo. Opinions expressed are the exclusive responsibility of the author and not necessarily represent ILO's.

(**) Doctor, Director of the Observatorio del Mercado de Trabajo, Universidad Externado de Colombia. E-mail: <sfarne@ gmail.com>. Received:16.05.2014, acept:20.06.2014. 


\section{INTRODUCTION}

The government of Juan Manuel Santos, President of Colombia starting August 2010 embarked on a radical shift in labour market policy.

The administration of President Uribe (2002-2010) gave great emphasis to stimulating investment through general tax exemptions and in particular for the acquisition of capital assets. At the same time, Uribe's administrationsignificantly raised contributions to social security, with the drawbackthat also the "pure" tax component of these contributions was increased. The minimum wage rose gradually, but steadily. Finally, from a broader macroeconomic context, the revaluation of the Colombian peso that began a decade ago must be highlighted.

All the mentioned events induced a profound change in relative prices of capital and labour, creating a strong anti-labour, anti-formal employment bias.

In order to reduce anti-labour bias and pressures on the productive sector arising from the revaluation of the currency, the new government considered of strategic importance to reduce the tax burden on companies hiring formal workforce. This strategy resulted in Act 1429 of 2010 on Formalization and Generation of Employment, and Act 1607 of 2012 on Tax Reform.

Three main sections compose this text. The first one is a theoretical framework that allows inferring the impact of payroll taxes on employment, within the context of a partial market equilibrium. A review of recent international empirical studies complements the analysis. In the second section, we examine Colombian experience in reducing social contributions by companies. Measures implemented are contextualized, and some preliminary occupational results are presented. The third section summarizes the main arguments presented throughout the text, and brings some policy lessons derived from the Colombian case.

\section{LABOURTAX AND EMPLOYMENT}

This section presents a standard theoretical model of the effects on labour market caused by changes in payroll taxes. It also proposes some criteria to follow when analysing these effects. Lastly, it summarizes the conclusions of a number of recent international microeconomic empirical studies that estimate the impact on employment of an across-the-board reduction of taxation to work.

\subsection{THEORETICAL ISSUES}

Economic theory comes to ambiguous conclusions at the time of setting forth the effects that may result on employment and wages from the introduction or changes in taxes on labour.

In the basic model, a perfectly competitive labour market without payroll taxes is in equilibrium when demand $D_{0}$ and supply $S_{0}$ are equal. The equilibrium wage is $w_{0}$ andemployment is set at $\mathrm{E}_{0}$ (Figure 1 ). Under these conditions, the wage paid by companies coincides with the wage received by employees. 
The introduction of a payroll tax causes an inward shift of the demand curve in the amount of $\operatorname{tax}_{1}$. The intersection of the newlabour demand curve $D_{1}$ with the original supply curve determines the wage employees now receive $\left(w_{1, \text { wo }}\right)$. In turn, demand curve $\mathrm{D}_{0}$ defines total labour costs per employee (wage plus tax) that now companies bear $\left(\mathrm{W}_{1, \mathrm{em}}\right)$. Although this is a payroll tax, it is clear that $\operatorname{tax}_{1}$ is not paid in full by employers, but rather is shared between employees and employers. The first ones contribute with an amount equal to $\mathrm{w}_{0}-\mathrm{w}_{1, \mathrm{wo}}$, and the second ones with an amount equal to $\mathrm{W}_{1, \mathrm{em}}-\mathrm{W}_{0}$.

The percentage of the tax that employees assume accepting lower wages is known as "pass-through" effect.

In a perfectly competitive market, within the framework of partial equilibrium, the "pass-through" depends entirely on supply and demand elasticities of labour to wages, $\left|\mathrm{E}_{\mathrm{s}, \mathrm{w}}\right|$ and $\left|\mathrm{E}_{\mathrm{d}, \mathrm{w}}\right|$ respectively, in absolute value:

$$
\text { pass through }=\frac{\left|\mathrm{E}_{\mathrm{d}, \mathrm{w}}\right|}{\left|\mathrm{E}_{\mathrm{d}, \mathrm{w}}\right|+\left|\mathrm{E}_{\mathrm{s}, \mathrm{w}}\right|}
$$

It is clear that the "pass-through" effect will be higher if the supply curve tends to be inelastic to wage and/or the demand curve tends to be elastic.

However, certain payments made by the employer, despite not being directly received by the employee, provide benefits to the latter, and may be considered as deferred wages. This is the case, for example, of contributions to pension and health, or unemployment insurance.

Summers (1989, p.180) claims that "Mandated benefits represent a tax at a rate equal to the difference between the employers cost of providing the benefit and the employee's valuation of it, not at a rate equal to the cost to the employer of providing the benefit".

If employees see the contribution paid by the company as payment for a service to their benefit, they will be willing to assume progressively its cost or work harder for the same wage. This induces an outward shift of the labour supply curve, leading to a reduction of wages actually paid by the company.

Finally, the "pass-through" effect may be limited by the existence of unions and mandatoryminimum remunerations that make wages rigid downwardly. Thus, facing an increase in payroll taxes, a union with bargaining power can avoid significant reductions in wages. Also, when the State sets a minimum wage, companies find it impossible to transfer the higher cost that affects the payroll composed by minimum wage workers to lower wages.

Obviously, the "pass-through" effect works in both ways, for payroll tax increases as well as tax reductions.

Back to Figure 1, suppose that $\operatorname{tax}_{1}$ is reduced to a level such as $\operatorname{tax}_{2}$, thus demand curve shifts from $D_{1}$ to $D_{2}$. As a result, total labour costs fall, but not in the same amount by which tax decreases, because part of the tax, equal to $\mathrm{w}_{2 \text {,wo }}-\mathrm{w}_{1 \text {,wo }}$, translates into higher wages for employees. 
So, if the "pass-through" is high, the effects of changes in payroll taxes are less significant, given that much of the increase (decrease) in taxes become lower (higher) wages and do not affect significantly the labour demand of companies.

Lastly, there are reasons to believe that the impact of payroll taxes on employment may have asymmetrical i.e., this is, that it may happen that reducing them may affect employment in a different quantity than an increase on taxes by the same magnitude (KESSELMAN, 1996, ARPAIA and CARONE, 2004, and KUGLER and KUGLER, 2008). This occurs because wages are more downward rigid (when payroll taxes increase) than upwards (when payroll taxes are reduced). In fact, in the case of the existence of a minimum wage, the law does not allow companies to reduce wages of employees hired with this wage if payroll taxes increase, this is, the "pass-through" effect is $0 \%$.However, if taxes go down, there is no law which prevents wages from increasing, in which case the "pass-through" effect may be other than $0 \%$. On the other hand, in the event of collective negotiation, employers and unions may perceive decreased payroll taxes as a "windfall gain” which they split among themselves without much dispute.

\subsection{HOW TO ESTIMATE EFFECTS OF TAX REDUCTION ON EMPLOYMENT}

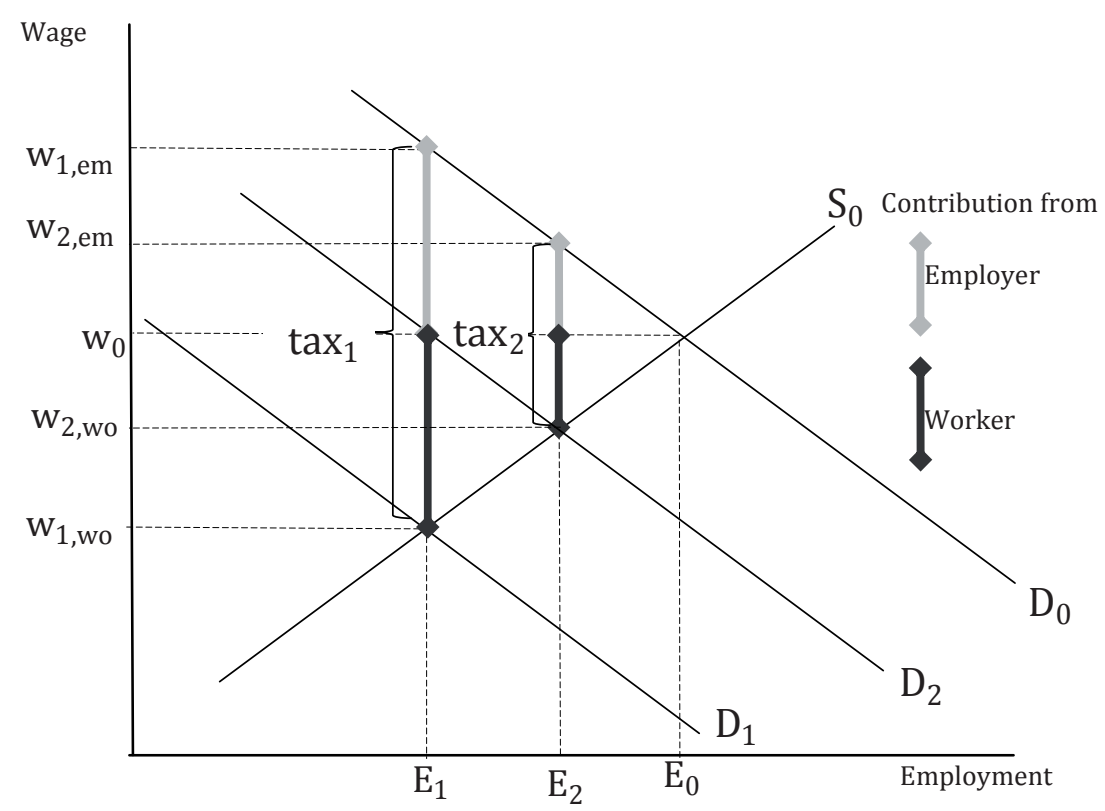

FIGURE 01

EFFECTS OF PAYROLL TAXCHANGES ON WAGES AND EMPLOYMENT

Source: Author's own assumptions

If the effect on employment of a labour tax reduction is not predictable a priori by economic theory, empirical estimation becomes crucial to derive indications of policy.

Thus, in order to derive a correct estimate of the employment effects of a reduction in labour taxes several points should be considered. 
First, and because the impact on employment of labour taxes, as documented before, has asymmetric features, we must recognize that empirical contributions that consider the employment effect of an increased payroll tax cannot be taken as a reference if, on the contrary, we want to know the impact produced by a reduction thereof.

Second, it should be clear that lowering taxes on labour does not lead to an equivalent reduction in labour costs. This would be possible only when the "pass-through" effect becomes null. This is a situation that an extensive international empirical literature tends to rule out.

Indeed, high "pass-through" rates have been found in developed countries (OOGHE et al., 2003, and AZEMAR and DESBORDES, 2010), in some cases close to $100 \%$. This means that a large part of changes in payroll taxes is transferred to workers by adjusting wages, so that the effect on employment results marginal. Melguizo and González-Páramo (2012, p. 247) base their meta-analysis work on 52 empirical studies, and conclude that "in the long run,workers bear between two thirds of the tax burden (on labour) in Continental and Anglo-Saxon economies, and nearly 90\% in the Nordic economies".

Also, when inspecting the experiences of some developed and developing countries, Taymaz (2006) concludes that in both cases much of the payroll tax is transferred to the wages of employees, and the "pass-through" effect would be greater than $50 \%$. In the specific case of Turkey, a transfer of about $70 \%$ was estimated.

According to the World Bank "research in Latin America suggests hat anywhere from 20-70\% of the employer's social security contributions are passed on to the worker" (WORLD BANK, 2009, p. 16). Higher values have been found by Gruber (1997) who in the case of Chile has found an almost total shift; by Cruces et. al. (2010) whom have calculated a "pass-through" effect between 40 and 90\% in Argentina; and by Kugler (2005) which has found that the wages of workers covered by a new system of severance payments decreased by between $60 \%$ and $80 \%$ of employers' contributions in Colombia.

Thus, in line with what theory predicts, in practice, companies manage to transfer a significant percentage of their mandatory contributions to the wages of its own employees. Vice versa, in the event taxes were lowered, employees would manage to seize a significant share of tax breaks Some final considerations should be made about the level of aggregation of the information used.

Usually empirical findings based on aggregate data make use of changes in labour taxes in both directions, without distinguishing cases of reductionsfrom increases.

On the other hand, when using time series and/or cross-sectional data there is the risk of obtaining biased results because of omission bias, measurement error, or endogenity of regressors ${ }^{(1)}$.

In fact, at macro level there can be reverse causality between occupational outcomes and labour taxes, being the first one-for example, an increase in unemployment or

(1) These potential drawbacks are highlighted throughout the empirical literature. Daveri (2002) addresses the issue in some depth. 
labour informality - that may influence the latter. Also, despite profuse efforts for its building, an important part of the variables considered in cross-sectionanalysis - such as employment protection indexes, institutional variables, indicators of bargaining power of unions, spending on active policies, etc. — are often only a first approximation of qualitative nature, and somehow subjective, of the phenomenon which wants to be studied. This makes them susceptible to measurement errors and endogenity. On the other hand, the lack of some relevant variable for the analysis can lead to omitted variable bias.

In contrast, microeconomic estimates are a more reliable alternative because they allow for checking differential effects of tax reductions between groups of individuals, companies, industries, or geographical areas, in the context of an identical institutional environment.

Summing up, to estimate the employment effects of a reduction in labour taxes, it is necessary to keep in mind that:

I. Estimates measuring the opposite causal relationship, that is how employment decreases if tax increases, do not serve as a guide;

II. The "pass through" effect should be taken into account;

III. The own microeconomic evidence of each country is more reliable.

\subsection{WHEN LABOUR TAXES DECREASE, EMPLOYMENT INCREASES? A REVIEW OF SOME INTERNATIONAL RESULTS}

Here are some national studies that meet the criteria outlined in the previous section.

\subsubsection{ARGENTINA}

Since 1995, Argentina has passed from a virtually uniform payroll tax at national level to a regional system. This process came along with a progressive reductions in these taxes between 1995 and 1999, and an increase from mid-2001, which, however, was not enough to keep the payroll taxes at initial levels (those of 1995). Cruces et. al. (2010) estimate the effects of these changes regionally differentiated on wages and formal employees of the urban private sector, and conclude that results "point to the absence of any significant effect on employment" (CRUCES et. al, 2010, p. 19). They conclude that "the main argument justifyingthe tax cuts introduced in 1995-1999 (namely, lower labor costs would increase employment) was not borne out by events."(CRUCES et. al, 2010, p. 20)

\subsubsection{TURKEY}

In order to encourage investment and employment growth in low-income regions, the Turkish government adopted a series of incentives in 1998 in favour of resident companies, which included among others, reductions in employer contributions to the social security. The geographical coverage of these benefits was extended to a greater number of provinces in 2004 and 2005. The World Bank has conducted a series of exercises to determine the occupational and fiscal impact of a possible tax reform in Turkey, based partly on the empirical assessment of the abovementioned provincial incentive programs. The synthesis report recognizes that "a major employment impact couldonly be achieved with verylarge reductions in labour taxes" (WORLD BANK, 2009, p. 30). 


\subsubsection{SWEDEN}

Bennmarker et al. (2008) studied the effects on wages and employment in Sweden after a reduction in payroll taxes in 2002. This reduction benefited small private sector companies located in certain remote and sparsely populated municipalities in the north of the country. Comparing them with a group of control enterprises with similar characteristics located in nearby areas, the authors "do not find that the regionally differentiated payroll tax has had any significant effects on employment” (BENNMARKER et al, 2008. p. 29).

\subsubsection{FINLAND}

Since January 2003, the Finnish government decided to reduce temporarily for three years the contributions to pension and health of firms located in 20 northern municipalities characterized by high unemployment. In subsequent years, these benefits were renewed twice until 2012, and extended to other municipalities in the east.

Korkeamäki and Uusitalo (2006) evaluate the effects on employment and wages per hour for the first two years of implementation of these measures. To this end, they define a group of enterprises located in municipalities not eligible for reductions, and with labour-demographic characteristics similar to the 20 beneficiary municipalities. As a result of the comparison between the two groups of companies, they find that in beneficiary regions about half of the reduction in social security contributions was passed to higher wages. The remaining reduction in the labour costs "did not have significant effect on employment growth” (KORKEAMÄKI and UUSITALO, 2006, p. 26).

In a similar exercise, Korkeamäki (2011, p. 31) extends the evaluation period until 2006. In this case, he also finds that "the payroll tax cuts did not have a statistically significant effect on total employment" in companies located in targeted geographic areas.

\subsubsection{CHILE}

Gruber (1997) examines the effects on wages and employment of reductions in payroll taxes that benefited Chilean firms in the early 80's. He estimates a panel of formal manufacturing firms, and finds statistically insignificant and small coefficients on employment, with an almost complete "pass-through". Therefore, he concludes that "the reducedcosts ofpayroll taxation to firms appear to have been fully passed on to workers in the form of higher wages, with little effect on employment levels" (GRUBER, 1997, p. 99).

\section{COLOMBIAN EXPERIENCE IN REDUCTIONS IN SOCIAL CONTRIBUTIONS}

This section presents the recent Colombian experience in payroll taxcuts to increase formal employment. The reasons and objectives, offered tax incentives, and goals on formal jobs set by Acts 1429 and 1607 are detailed and discussed. The expectedimpact on employment is confronted with some first available labour statistics. 


\subsection{ACT 1429 OF 2010 ON FORMALIZATION AND EMPLOYMENT GENERATION}

As noted in the explanatory statement of purpose, Act 1429 seeks to alter the cost/ benefit relationship between informality and formality in the first years of operation of small companies. At the same time, it seeks to increase employment opportunities for some populations at risk of labour exclusion. To this end, it provides a reduction of taxes and social contributions for small formal companies (Companies with up to 50 employees.) that start-up activities and for all companies, regardless of their size, which increase their payroll by hiring disadvantaged workers.

Reductions provided for new small businesses involve three categories of taxes:

I. Mercantile Registry and its annual renewal. In order to benefit from these, companies must register as beneficiary of Act 1429 at the Chamber of Commerce;

II. Income tax and withholding tax. In this event, the benefit must be requested from the Tax and National Customs Office (DIAN, for its Spanish initials);

III. Contributions to workers' health, SENA, ICBF, and "cajas de compensaciónfamiliar" (for a total of $10.5 \%$ of basic payroll). Verifying compliance with the payment of these social contributions is the responsibility of the Pension Management Unit (UGPP, for its Spanish initials) of the Ministry of Finance of Colombia.

While the gateway to access these three discounts is only one, which is the entry in a register of beneficiary enterprises at the Chamber of Commerce, companies that enjoy the reduction in the fare of the commercial registration may refrain from claiming other benefits.

All reductions provided by the Act are decreasing in time, and extinguish on the sixth year of operation of the company, according to the schedule reported in Table 1. The taxation benefits have an indefinite term, while the lower payroll taxes and discounts on the value of the commercial registration may only be benefited by the companies abiding by Act 1429, until December 31논, 2014.

\begin{tabular}{|c|c|c|c|c|}
\hline & $\begin{array}{l}\text { Me rcantile } \\
\text { regis try and } \\
\text { its re newal }\end{array}$ & $\begin{array}{l}\text { Withholding } \\
\qquad \operatorname{tax}\end{array}$ & Income Tax & $\begin{array}{c}\text { Payroll taxes } \\
\text { and } \\
\text { FOSYGA } \\
\text { payments } \\
\end{array}$ \\
\hline $\begin{array}{c}\text { Year of } \\
\text { operation }\end{array}$ & $\begin{array}{c}\% \text { of the fare } \\
\text { to pay }\end{array}$ & $\begin{array}{c}\% \text { of the fare } \\
\text { to pay }\end{array}$ & $\begin{array}{c}\% \text { of the fare } \\
\text { to pay }\end{array}$ & $\begin{array}{c}\% \text { of the fare } \\
\text { to pay }\end{array}$ \\
\hline 1 & $0 \%$ & \multirow{4}{*}{$\begin{array}{c}\text { not subject to } \\
\text { withholding } \\
\text { tax }\end{array}$} & $0 \%$ & $0 \%$ \\
\hline 2 & $50 \%$ & & $0 \%$ & $0 \%$ \\
\hline 3 & $75 \%$ & & $25 \%$ & $25 \%$ \\
\hline 4 & $100 \%$ & & $50 \%$ & $50 \%$ \\
\hline 5 & - & - & $75 \%$ & $75 \%$ \\
\hline 6 & - & - & $100 \%$ & $100 \%$ \\
\hline
\end{tabular}

CHART 01

TAX BENEFITS FOR THE NEW SMALL ENTERPRISES UNDER THE ACt 1429 OF 2010 
On the other hand, companies that increase their payroll relative to December of the previous year by hiring young people up to 28 years old, internally displaced persons, disabled people, people in process of social reintegration, low-income breadwinner, women over 40 years, and any new employee earning less than 1.5 monthly minimum wage, may use part of social contributions paid as tax deduction for purposes of determining income tax. The right to tax benefit will not expire, but for each individual hired company may be favoured by a maximum of two years.

There are reasons to believe that, contrary to what the government had claimed, lower costs provided may not be a sufficient stimulus to induce formalisation.

In fact, during the first years of existence, it is expected that companies do not make profits on which to calculate income tax. Then, tax reductions provided during the first years of operation do not translate into significant savings for small businesses, in practice.

Lower costs for mercantile registry according to the Chamber of Commerce of Bogota (CALDAS, 2011) resulted in an average saving of about USD\$ 60, in 2011; in the case of companies of individuals this saving was even lower: on average a little over USD\$ 25.

Finally, savings that can result from payroll tax reductions are approximately $6.1 \%$ of the total labour cost -this is includingall wage and non-wage costs, such as bonuses, severance payments, social contributions, etc. - during the first two years, $4.6 \%$ in the third year, $3 \%$ in the fourth year, and $1.5 \%$ in the fifth year. As in the case of commercial registration, those are obviously not large sums of money.

Tax incentives for job creation within disadvantaged groups of workers are more relevant. All companies can deduct from their income tax an amount equal to $12 \%$ of base wage of new employees ${ }^{(2)}$. In this case, however, the benefit expires at the end of the second year of hiring each individual, and the principle of additionality, - i.e.,every year, the payroll of the beneficiary company must exceed the recorded as of December $31^{\text {st }}$ of the year immediately previous - becomes a very demanding condition. Indeed, it is hard to think that companies manage to increase the number of employees ad infinitum, year after year.

The results of follow-up to statistics available to date are presented, and beneficiary companies of Act 1429 are identified in first instance.

According to UGPP, the entity in charge of monitoring the full implementation of the thorough application of social deductions foreseen in favour of new small formalized businesses, a total of 239,400 companies were registered at the Chambers of Commerce as potential beneficiaries of Act 1429, in 2011. 41.1\% of them declared not to have permanent staff at the time of registration; another 36.5\% reported having one worker, not being able to distinguish whether it was the owner himself or a wage-dependent worker.

(2) And corresponding to payments to cajas de compensación familiar, SENA, and ICBF, in addition of 1,5\% paid to the Fondo de Garantía de PensiónMínima (Minimum Pension Guarantee Fund), and 1,5\% of solidarity contribution to the Fondo de Solidaridad y Garantía del Sistema de Salud - FOSYGA (Solidarity and Guarantee of the Health System Fund). 
Out of these 239.400 companies only 6.707 (3\%) made contributions to social security on behalf of an employee, taking advantage of non-payment of $11.5 \%$ on the corresponding basic payroll, in 2011 (UGPP, 2012). According to DIAN, companies that met the requirements to reduce income tax were even less during the same year: 6.441 (DIAN, 2013).

A year and three months later the situation had not improved substantially: only $4 \%$ of companies benefiting at any time since the validity of the act decided to enjoy the tax discount (UGPP, 2013).

If only $4 \%$ of the benefiting companies of Act 1429, at some point during the firsttwo years and three months of itsvalidity have made reduced social security contributions, it is reasonable to infer that the impact on employment of the aforementioned law must be of similar dimensions.

In fact, during the same period, 17.327 companies paid at least one month of contributions to 225.736 employees (UGPP, 2013). This figure is far from the government's target of 500.000 jobs formalized as exclusive result of Act 1429. Moreover, it should be resized taking into account that only "57\% of the companies benefiting from Act 1429 timely paid contributions to social security during the time elapsed of the law" (UGPP, 2013), and that part of the workers were employed on a temporary basis, this being a form of contracting particularly relevant in new and small businesses. So, the number of employees hired monthly by companies benefiting from the Act of Formalization only rarely exceeded 100.000 units. In March 2013 they were 88.809 employees. And even if they are added to the 33.099 employees of companies under Act 590, the total would be 121.908 formalized jobs (UGPP, 2013) ${ }^{(3)}$.

Naturally, the commented formalization of businesses and jobs is not necessarily attributable entirely to Act 1429 , nor this was the only factor involved in the decision to formalize.

Official figures on the number of new companies that took advantage of the law do not allow for this distinction, and therefore, overestimate the true impact of it. Economic growth or business formalization programs held by the Chambers of Commerce in the entire country, for example, may have been the main cause for the legalization of numerous productive activities that were informal previously. Only a rigorous impact evaluation can solve these problems of causality.

In turn, there is no information of the generation of formal employment among disadvantaged workers to date, because in the form of income tax there is no box to identify the jobs and deductions made by companies based on Act 1429 .

\subsection{ACT 1607 OF 2012 ON TAX REFORM}

Less than two years after the enactment of Act 1429, another time the Colombian government evoked the argument of high informality to pass a tax reform in the Con-

(3) Act 590 of 2000 provides that micro, small, and medium enterprises can enjoy a $75 \%$ reduction of the total value of their contributions to SENA, ICBF, and cajas de compensación familiar in the first year of operations; $50 \%$ in the second one, and $25 \%$ in the third. Act 1429 leaves the possibility that beneficiary companies may choose to abide by payroll tax reductions established in it or by those, less generous, provided in Act 590. 
gress. In this opportunity Act 1607 of December 2012 changed again the rate of social security contributions paid by enterprises.

Formally, companies remain responsible for funding the ICBF, SENA, and health of their employees, but now the necessary resources for such purposes do not originate anymore in $13.5 \%$ of the monthly value of theirpayroll. As an alternative, a new hypothecated income tax called "forthe equity" CREE of 8\% (9\% for the first three years) was created.

At the same time, however, the overall rate of income tax decreases in 8 percentage points, from 33 to $25 \%$. In the end, then, companies would avoid paying $13.5 \%$ of social contributions that end up being charged, largely, to individuals for which direct tax burden increases. The reduction in payroll taxes does not apply to companies not subject to income tax (public sector, foundations, NGOs, for example), and to employees of taxpayer companies with income higher than ten minimum monthly wages.

Besides the changes just described, the tax reform introduced changes to the system of indirect taxes, and its promoters argue having conceived it to have a neutral effect on the total tax receipts.

With the relief derivable from minor taxes on labour, the National government sought to favour labour-intensive companies, and expected to generate between 400.000 and 1.000.000 new formal jobs.

Although Act 1607 was enacted in December 2012, the employers' obligation to fund the SENA and ICBF with a contribution of $5 \%$ of basic payroll was eliminated only from May 2013 onwards, and the contribution of $8.5 \%$ for employees' health was removed only starting January $1^{\underline{s t}}$, 2014. So, today it is impossible to empirically assess its consequences on employment. It should be noted that, as in the case of Act 1429, Act 1607 does not have a baseline at a period of time before its implementation.

Then, we will proceed with an ex ante appraisal that will try to verify the theoretical consistency between the policy implemented and desired results. To this end, some initial clarifications are necessary.

First, it should be noted that $13.5 \%$ of payroll taxes are assessed on the basic wage, and, therefore represent a lower percentage of total labour costs. The Ministry of Finance of Colombia recognizes that" a reduction of $13.5 \%$ in employer contributions represents a fall of $8 \%$ in their current labour costs" (CÁRDENAS, 2012).

Second, we must draw attention to the desirable consistency between wage policy and payroll reduction. It is clear that, in the short run, increases in real wages go in the opposite direction and reduce the expected employment creation stemming from lower labour taxes. In this sense, the rise in the minimum wage decreed by the Colombian government within days of passage of Act 1607-1.6 percentage points above inflation in the preceding year- partly offset the reduction in labour costsendorsed by tax reform. In the same vein, the 2014 minimum wage increase was 2.6 percentage points higher than inflation in 2013, being the highest in the last twenty years. 
Third, tax reform has led to a broadening of the income-tax base and inevitably increased the effective rate. This is a result of the tax reform little publicised, but unmistakable: in practice, the income tax to enterprises has increased noticeably. This is mainly for two reasons.

On the one hand, employers cannot deduct social contributions (SENA, ICBF and health) as a cost in the income tax because they are not paying them under the act. Clearly labour intensive companies end up suffering more than capital-intensive companies, because they were benefiting most from the reduction in payroll taxes. On average, it is expected that the rate of income tax will go up 1-2percentage points (FARNÉ, 2013).

Furthermore, exempt income and allowable deductions in determining the taxable base for the new CREE tax were slashed relative to general income tax. On average, according to the Ministry of Finance of Colombia, the collection will increase by $20 \%$ (see Ministry of Finance of Colombia, 2012), so that 8\% in the CREE rate translates into 9.6 $\%$ of the general income tax rate.

In years 2013 to 2015 the CREE rate willnot be $8 \%$ as proposed by the Government, but $9 \%$ as approved by the Congress.In terms of the general income tax rate there is another $1.2 \%$ to take into account.

With the mentioned caveats, the effective rate of income tax-adjusted will rise nearly five percentage pointsfor companies on average, from 33\% before Act 1607 to about $37.8 \%$ for the tax year 2013 .

Fourth, and as noted above, the companies did not pay the contribution of $5 \%$ on payroll with SENA and ICBF destination only from May 2013 and the $8.5 \%$ contribution to health of its employees was removed from January 2014. At the same time, during 2013 they paid CREE new tax. Hence, in 2013 companies paid twice the contributions to health, SENA and ICBF.

In conclusion, the reduction in payroll taxes has not been what was projected. In part it has been "passed through" to workers via higher wages and in part it also has been offset by higher income taxes.

This could lead to little employment gains. A simple exercise carried out by the Observatorio del Mercado de Trabajoof the Universidad Externado of Colombia has concluded that tax reform could provide 50.000 to 85.000 new jobs (FARNÉ and RODRÍGUEZ, 2013). A figure rather lower than expected by the government, but consistent with the results from other studies. For example, according to the general equilibrium model of Hernández (2011), the replacement of nine percentage points of payroll taxes by another type of tax would have no effect on the rate of unemployment and reduce only $1 \%$ the informality rate. Also, the substitution of the same nine percentage points with indirect taxes leads to an increase of only 157.000 formal jobs according toBotero (2011). It is worth to notice that, differently from the case of laws 1429 and 1607, this two exercises applied tax cuts to all firms and employees in the economy.

Employment data relating to the first year of implementation of Act 1607 confirms the veracity of these estimates. Although economic growth was slightly higher - GDP 
grew $4.0 \%$ in 2012 relative to $4.3 \%$ in 2013 - the creation of formal wage-employment in the private sector actually favoured by the tax reform was reduced after the Act. According to the Institute of Statistics of Colombia (DANE for its Spanish initials) in this sector 285.369 new jobs were created in 2012, but only 260.165 in 2013; this is about 25.000 jobs less. Moreover, in 2013 the new jobs were concentrated in the capital intensive financial sector, in the educational sector (not income tax payerand so not entitled to payroll tax reduction) and high wage employees (for whom payroll tax cut does not apply).

Nationally, the growth rate of total employment collapsed from 3.4\% in 2012 to just $1.7 \%$ in 2013 (see Table 2).

\begin{tabular}{|c|c|c|c|c|c|}
\hline \multirow{2}{*}{$\begin{array}{c}\text { Inter-year } \\
\text { variation: }\end{array}$} & \multirow{2}{*}{$\begin{array}{c}\text { GDP } \\
\text { growth }\end{array}$} & \multicolumn{2}{|c|}{$\begin{array}{c}\text { Anual change of total } \\
\text { employment }\end{array}$} & \multicolumn{2}{c|}{$\begin{array}{c}\text { Anual change of employees in } \\
\text { (formal) favoured sectors * }\end{array}$} \\
\cline { 3 - 6 } & & Absolute & Percentage & Absolute & Percentage \\
\hline $2011-2012$ & 4,0 & 676.907 & 3,4 & 285.369 & 6,7 \\
\hline $2012-2013$ & 4,3 & 351.776 & 1,7 & 260.165 & 5,8 \\
\hline
\end{tabular}

ChART 02

\title{
Gross Domestic Product growth and average annual change of EMPLOYMENT IN COLOMBIA
}

Years 2012 and 2013

\begin{abstract}
* Employees in formal sector activitiesfavoured by tax reform: all formal employees (ILO definition) except those working in telecommunications, education, financial, mining and utilities sectors, and those earning more than ten minimum monthly wages in any sectors. Public officials are also excluded.
\end{abstract}

Source: Author's calculations based on DANE household surveys and national economic accounts.

\section{CONCLUSION: POLICY IMPLICATIONS}

The formalization strategy of the Colombian government has been based on the belief that informality is the result of a rational choice of economic agents that compare the benefits and costs of being formal. In practice, however, both Act 1429 and 1607 neglect the benefits making emphasis only in costs side.

The expectation of the government is that all or most of the reduction in social contributions becomes a reduction of labour costs, with no counteracting response from labour supply. And further, that this reduction in costs is sufficient to reverse the outcome of the trade-off between costs and benefits of the formality. Apparently, neither of the two facts occurred.

The experience of Colombian Acts 1429 and 1607 leaves several policy lessons.

First, it is very likely that the reduction in labour taxes needs compensatory fiscal measures (unless this reductionis only temporary). Upon the Colombian tax reform, all private sector companies will pay less payroll taxes, but more income taxes, and this will 
attenuate the expected employment impact. In particular for intensive human and physical capital companies it is likely an increase in total taxes (adding up income and payroll taxes) associated with the level of staff employed at the time of entry into effect of Act 1607. Consequently, the tax reform will generate very little incentives to hire more employees in the telecommunications, financial, mining, and utilities sectors. Many hotels, restaurants, and bars are in similar conditions due to changes introduced to the tax regime for indirect taxes and VAT.

Second, in order to effectively generate employment there should be consistency between reduction of social contributions and wage policy. In Colombia, minimum wage increases partially offset the decrease in labour taxes, making more expeditious the transfer of these lower taxes to higher wages.

This brings us to a third important consideration raised by economic theory: the existence of a "pass-through" effect, which predicts that a decrease in labour taxes does not result in an equal reduction in labour costs. Econometric estimates have found that the former can be higher than thelatter, although the magnitude of the difference varies from case to case, depending on the type of tax, group of employees affected and current macroeconomic and institutional context.

A corollary of this third point is that not all the value of social contributions that companies pay for their employees can be considered a tax, as suggested by Summers (1989). Indeed, some payments give access to benefits to the workers. Consequently, the policy of reducing costs of being formal cannot be indiscriminate. Rather, it should operate solely on the "pure" tax component of these contributions.

Fourth, the Colombian government ignored not only the empirical contributions of the abundant international literature (which agrees in non-significant impacts on employment as a result of a reduction in payroll taxes), but also some important policy recommendations present in the literature. Both the report of Econopubblica (2011) for the European Commission and the World Bank for Turkey recommend not to proceed to a widespreadcut in labour taxes. Rather, they recommend to focus on unskilled labour, minimum wage workers, or specific groups (such as breadwinner women or youth). For these categories of employees the "pass-through" effect is much smaller than for other employees, and consequently, the effect on employment is greater.

All in all, the average effective cost reduction for hiring that involved Acts 1429 and 1607 may have resulted insufficient to cause the employment impact expected by its promoters.

In Colombia there are other factors different from labour costs, which are likely to have greater weight in the decision to become formal and formalize staff employed by small productive units. Among them, we can finda production scale too small to hire employees, or the complexity and little friendliness of the tax system, or a poorly designed system of financing social protection.

Clearly, the formalization strategy chosen by the Colombian government has not been effective for individuals who are forced to belong to the informal sector because they do not have any other choice, and the comparison between costs and benefits of 
the formality is not an option; that is for those excluded from formality due to low productivity, poverty or poor education.

\section{BIBLIOGRAPHY}

ARPAIA, Alfonso; CARONE Giuseppe. Do labour taxes (and their composition) affect wages in the short and in the long run?, Economic Papers, European Commission, n. 216, 2004.

AZEMAR, Celine; DESBORDES Rodolphe. Who ultimately bears the burden of greater non-wage labour costs?, University of Strathclyde, Discussion Papers in Economics, n. 10-04, Glasgow, 2010.

BARAN, Joni. Payroll taxation and employment: A literature survey, Industry Canada, Occasional Paper, n. 15, 1996.

BENNMARKER, Helge; MELLANDER Erik; OCKERT Bjorn. Do regional payroll tax reductions boost employment? IFAU. Working Paper, n. 2008: 19, page 33, 2008.

BOTERO, Jesús. Desempleo e informalidad en Colombia. Un modelo de equilibrio general computable (Unemployment and informality in Colombia. A model of computable general balance), mimeo, Universidad EAFIT, Medellín, page 28, 2011.

CALDAS, Consuelo. Formalización empresarial: avances y retos (Enterprise formalization: progresses and challenges), presentation to the 48 Confecámaras National Meeting (48 Asamblea Nacional Confecámaras), Chamber of Commerce of Bogota, Cartagena, September 22 $\frac{\text { nd }}{2}, 2011$.

CÁRDENAS, Mauricio. Reforma tributaria 2012 (2012 TaxReform), PPT presentation, Bogota, October $26^{\text {th }}, 2012$.

CRUCES, Guillermo; GALIANI Sebastian; KIDYBA Susana. Payroll taxes, wages and employment: identification through policy changes, CEDLAS, Documento de Trabajo, n. 93, 2010.

DAVERI, Francesco. Labour taxes and unemployment. A survey of the aggregate evidence, CeRP Working Paper, n. 18, 2002.

DIRECCIÓN DE IMPUESTOSY ADUANAS NACIONALES-DIAN. Primer informe sobre la aplicación de la Ley 1429 de 2010 (Firstreportontheapplication of Act 1429 of 2010), Coordinación de Estudios Económicos, Cuaderno de Trabajo, n. 49, 2013.

ECONOPUBBLICA. The role and impact of labour taxation policies, Informe para la Comisión Europea (Report for the European Commission), Milan, 2011.

FARNÉ, Stefano. Reformatributaria, empleo e informalidad (Tax reform, employment, and formality), PPT presentation, Valledupar, July 25 2013.

FARNÉ, Stefano; RODRÍGUEZ David. ¿Bajar los impuestos al trabajo genera empleo? (Doesloweringlabourtaxgenerateemployment?) Act 1607 of 2012, of taxreform in Colombia, social Security Officel, Cuaderno de Trabajo, n. 14, Universidad Externado de Colombia, 2013.

GRUBER, Jonathan. The incidence of payroll taxation: Evidence from Chile, Journal of Labour Economics, v. 15, n. 03, p. S72-S101, 1997.

HERNÁNDEZ, Gustavo. Impuestos parafiscales y mercado laboural: un Análisis de equilibrio general computable (Parafiscal taxes and labourmarket: ananalysis of computable general balance), Archivos de Economía, n. 378, p. 20, 2011.

KESSELMAN, Jonathan. Payroll taxes in the finance of social security, Canadian Public Policy, v. 22, n. 02, p. 162-179, 1996.

KORKEAMAKI, Ossi. The finnish payroll tax cut experiment revisited Government Institute for Economic Research, VATT Working Paper, n. 22, 2011. 
KORKEAMAKI, Ossi; UUSITALO Roope. Employment effects of a payroll-tax cut. Evidence from a regional tax exemption experiment, IFAU. Working Paper, n. 10, 2006.

KUGLER, Adriana. Wage-shifting effects of severance payments savings accounts in Colombia, Journal of Public Economics, v. 89, p. 487-500, 2005.

KUGLER, Adriana; KUGLER Maurice. Labour market effects of payroll taxes in a developing countries. Evidence from Colombia, NBER Working Paper, n. 13.855, p. 33, 2008.

MELGUIZO, Angel; GONZÁLEZ-PÁRAMO José. Who bears labour taxes and social contributions? A meta-analysis approach, Journal of the Spanish Economic Association, p. 247-271, 2012.

MINISTRY OF TREASURY OF COLOMBIA.Reformatributaria para la equidad y el empleo (Tax reform for the quity and unemployment), PPT presentation, December, 2012.

OOGHE, Erwin; SCHOKKAERT Erik; FLECHET Jef. The incidence of social security contributions: an empirical analysis, Empirica, v. 30, n. 02, p. 81-106, 2003.

SUMMERS, Laurence. What can economics contribute to social policy?,American Economic Review Papers and Proceedings, v. 79, n. 02, p. 177-183, 1989.

TAYMAZ, Erol. Labourdemand in Turkey, Informe para el Banco Mundial, mimeo, page 51, 2006.

UNIDAD DE GESTIÓN PENSIONAL Y PARAFISCALES - UGP. Desarrollo metodológico. Selección de empresas con indicios de incumplimientos de requisitos de Ley 1429 Methodologicdevelopment. Selection of companies with indication of non-compliance of requirmeents of Act 1429), PPT presentation, 2013.

UNIDAD DE GESTIÓN PENSIONAL Y PARAFISCALES - UGP. Comunicado de prensa (Press release), March 30 2012. 